University of Nebraska - Lincoln

DigitalCommons@University of Nebraska - Lincoln

USGS Staff -- Published Research

US Geological Survey

4-18-2005

\title{
Patterns of fish use and piscivore abundance within a reconnected saltmarsh impoundment in the northern Indian River Lagoon, Florida
}

Philip W. Stevens

Department of Environmental Engineering Sciences, University of Florida \& Florida Integrated Science Center, U.S. Geological Survey, philip.stevens@myfwc.com

Clay L. Montague

Department of Environmental Engineering Sciences, University of Florida

Kenneth J. Sulak

Florida Integrated Science Center, U.S. Geological Survey

Follow this and additional works at: http://digitalcommons.unl.edu/usgsstaffpub

Part of the Geology Commons, Oceanography and Atmospheric Sciences and Meteorology Commons, Other Earth Sciences Commons, and the Other Environmental Sciences Commons

Stevens, Philip W.; Montague, Clay L.; and Sulak, Kenneth J., "Patterns of fish use and piscivore abundance within a reconnected saltmarsh impoundment in the northern Indian River Lagoon, Florida" (2005). USGS Staff -- Published Research. 1075.

http://digitalcommons.unl.edu/usgsstaffpub/1075

This Article is brought to you for free and open access by the US Geological Survey at DigitalCommons@University of Nebraska - Lincoln. It has been accepted for inclusion in USGS Staff -- Published Research by an authorized administrator of DigitalCommons@University of Nebraska - Lincoln. 


\title{
Patterns of fish use and piscivore abundance within a reconnected saltmarsh impoundment in the northern Indian River Lagoon, Florida
}

\author{
Philip W. Stevens ${ }^{1,2, *}$, Clay L. Montague ${ }^{1}$ and Kenneth J. Sulak ${ }^{2}$ \\ ${ }^{1}$ Department of Environmental Engineering Sciences, University of Florida, P.O. Box 116450, Gainesville, FL \\ 32611; ${ }^{2}$ Florida Integrated Science Center, U.S. Geological Survey, 7920 NW 71 St, Gainesville, FL 32653; \\ *Author for correspondence: Present address: Florida Fish and Wildlife Conservation Commission, Fish and \\ Wildlife Research Institute, Charlotte Harbor Field Lab, 1481 Market Circle, Unit 1, Port Charlotte, FL \\ 33953 (e-mail: philip.stevens@myfwc.com; phone: +1-941-255-7403; fax: +1-941-255-7400)
}

Received 8 February 2005; accepted in revised form 18 April 2005

Key words: Fish movements, Nursery habitat, Trophic relay, Wading birds

\begin{abstract}
Nearly all saltmarshes in east-central, Florida were impounded for mosquito control during the 1960s. The majority of these marshes have since been reconnected to the estuary by culverts, providing an opportunity to effectively measure exchange of aquatic organisms. A multi-gear approach was used monthly to simultaneously estimate fish standing stock (cast net), fish exchange with the estuary (culvert traps), and piscivore abundance (gill nets and bird counts) to document patterns of fish use in a reconnected saltmarsh impoundment. Changes in saltmarsh fish abundance, and exchange of fish with the estuary reflected the seasonal pattern of marsh flooding in the northern Indian River Lagoon system. During a 6-month period of marsh flooding, resident fish had continuous access to the marsh surface. Large piscivorous fish regularly entered the impoundment via creeks and ditches to prey upon small resident fish, and piscivorous birds aggregated following major fish movements to the marsh surface or to deep habitats. As water levels receded in winter, saltmarsh fish concentrated into deep habitats and emigration to the estuary ensued $(200 \%$ greater biomass left the impoundment than entered). Fish abundance and community structure along the estuary shoreline (although fringed with marsh vegetation) were not analogous to marsh creeks and ditches. Perimeter ditches provided deep-water habitat for large estuarine predators, and shallow creeks served as an alternative habitat for resident fish when the marsh surface was dry. Use of the impoundment as nursery by transients was limited to Mugil cephalus Linnaeus, but large juvenile and adult piscivorous fish used the impoundment for feeding. In conclusion, the saltmarsh impoundment was a feeding site for piscivorous fish and birds, and functioned as a net exporter of forage fish to adjacent estuarine waters.
\end{abstract}

\section{Introduction}

Saltmarshes in east-central Florida became isolated from the Indian River Lagoon system when they were impounded for mosquito control during the 1960s. As a result, 16,200 ha of potential nursery habitat for estuarine fish were removed from the estuary (Brockmeyer et al. 1997), and production of small saltmarsh fish was trapped behind a system of dikes, unavailable for 
consumption by estuarine predators. Subsequent studies documented the deleterious effects of impounding on estuarine fishes (Gilmore et al. 1982; Harrington and Harrington 1982; Rey et al. 1990a), and an aggressive program was initiated to reconnect saltmarsh impoundments to the Indian River Lagoon by culverts (Brockmeyer et al. 1997).

Once reconnected, primary producers, nutrient and detrital storages, and fundamental trophic interactions within saltmarsh impoundments may be similar to unaltered systems. The distinguishing features of impoundments are the system of dikes and borrow ditches that surround the perimeter of the marsh (i.e., perimeter ditches), and culverts that provide aquatic exchange to the adjacent estuary. Perimeter ditches within impoundments, although artificial, are similar to creeks in other marsh systems. They may provide similar refuge from predation, a conduit for transport of materials from marsh to estuary, and access to predators seeking prey when water control structures are open to the estuary (Gilmore et al. 1982; Rey et al. 1990b). Exchange of water, detritus, nutrients, and aquatic organisms between the marsh system and the adjacent estuary is confined to culverts, where water control structures may be opened or closed depending on management objectives (e.g., resource management, mosquito control).

A primary concern regarding impoundments has been reduction of access to saltmarshes by estuarine nekton where water control structures are managed, especially for those species that depend on marshes during early stages of their life history (Montague et al. 1987; Rogers et al. 1994; Brockmeyer et al. 1997). Where water level management is not a priority, impoundments can be left open year round to optimize access for wetland-dependent fishes and invertebrates (Brockmeyer et al. 1997).

Impoundments where culverts are open yearround are directly subject to the hydrology of adjacent waters. Saltmarshes in the northern Indian River Lagoon system lie at the extremities of three lagoons (Indian River Lagoon, Banana River, and Mosquito Lagoon). Waters of these lagoons are isolated from the ocean and have little or no diurnal tidal range $(<5 \mathrm{~cm})$ (Smith 1986). Short-term changes in water levels and circulation are primarily driven by wind.
Long-term changes in water levels are dramatically influenced by seasonal variations in sea level. Water levels are typically low in spring and summer, but about $27 \mathrm{~cm}$ higher in fall due to thermal expansion and seasonal rainfall (Smith 1986). Due to this seasonal variation in water level, many Indian River Lagoon marshes are dry during much of summer, but almost continuously inundated during fall and early winter (Provost 1973; Smith 1986).

Hydrology of the northern Indian River Lagoon System may be similar to other seasonally flooded and wind-driven estuaries (e.g., Pamilco Sound, North Carolina, Laguna Madre, Texas, and Camargue, southern France), but differs greatly from more typical tidal marshes such as those in Georgia where daily tides are predictable and tidal range masks seasonal changes in water level. In contrast to marshes affected by daily tides, the cycle of fish movements to and from the marsh surface in seasonally flooded marshes is expanded over many months, rather than hours. Thus, movement of saltmarsh resources across the landscape by trophic interactions among resident (those species able to complete their life history within the marsh) and larger transient species (those species that use marshes during their early life history) via the trophic relay (Kneib 1997) may occur on similar time scales. Direct movement of resident fish to the estuary may be especially important in the Indian River Lagoon system where hydrology is seasonal and relatively narrow marshes are in close proximity to open estuarine waters. Thus, understanding relationships among predator-prey interactions, fish movements, and differential use among marsh habitats has direct relevance to fish use of marshes as nursery, and transfer of saltmarsh production to adjacent estuarine waters by fish.

Studies conducted within Indian River Lagoon saltmarshes have measured fish densities and diversity (Harrington and Harrington 1961; Gilmore et al. 1982; McLaughlin 1982; Rey et al. 1990a, b; Karlen 1991; Lin and Beal 1995; Klassen 1998; Faunce and Paperno 1999; Poulakis et al. 2002), fish exchange between reconnected impoundments and the lagoon (Wieher 1995; Taylor et al. 1998), and bird abundance (Smith and Breininger 1995), but none have measured these parameters simultaneously. Integrating the above studies to effectively describe 
patterns of fish use and piscivore abundance is difficult, because data were collected in different places and at different times, concealing potential relationships. For example, fish standing stock depends on the instantaneous rate that fish are entering and leaving the impoundment and the rate at which they are being preyed upon. Abundance of piscivores within the impoundment may depend on fish standing stock, rate of fish movement into the impoundment, and water conditions. Measuring various components concurrently using a systems level approach enables researchers to establish the fate of fish in saltmarsh habitat as they become food for piscivores or exchange with estuarine waters. The objective of this study was to take advantage of the impoundment situation (definitive saltmarsh boundaries and fish exchange confined to culverts) to simultaneously measure fish exchange, fish standing stock, and piscivore abundance to document patterns of fish use within a reconnected saltmarsh impoundment in the northern Indian River Lagoon.

\section{Methods}

\section{Study area}

Merritt Island National Wildlife Refuge (Figure 1), lies along the transition between temperate and subtropical climate in Florida where mangroves and saltmarsh alternate in response to periodic freezes that reset mangrove development (Kangas and Lugo 1990; Stevens 1999). Saltmarsh plant species covered the marshes after consecutive freezes in the 1980s killed existing mangrove forests consisting of some Rhizophora mangle L., and many Avicennia germinans (L.) and Laguncularia racemosa (L.). However, dead mangrove wood and fringing live L. racemosa remain conspicuous features of the estuarine shorelines. The vegetation typical of seasonally flooded marshes at Merritt Island consists of Distichlis spicata (L.), Paspalum vaginatum Sw., Batis maritima L., and Spartina bakerii Merr. Spartina alterniflora Loisel. may fringe the estuary shoreline, but is seldom found on the marsh surface. Merritt Island's transitional location enhances the diversity of nekton communities, as both temperate and subtropical fishes co-exist (Snelson 1983).

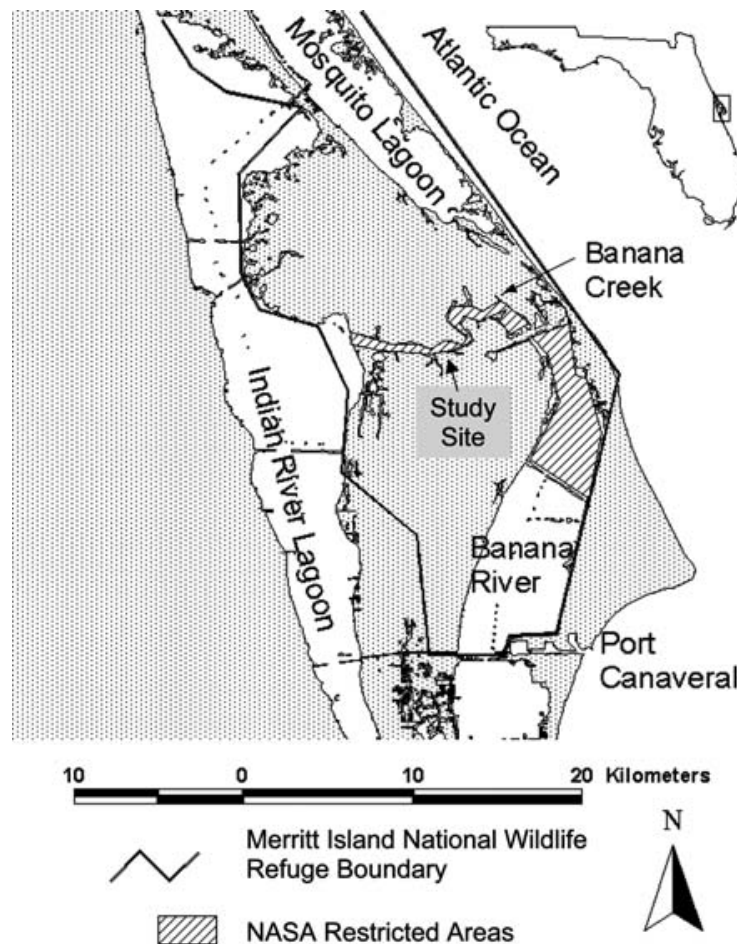

Figure 1. Location of study site within the northern Indian River Lagoon system.

The selection criteria for the study impoundment included the following: the impoundment was covered by saltmarsh vegetation indicative of Merritt Island (as opposed to exotic marsh plants or predominately upland species), culverts were open year round to allow the exchange of aquatic organisms between the impoundment and the estuary, the culverts had been open for several years so the ecological community was not undergoing dramatic successional changes during the study period, and adequate access to the impoundment by project personnel was available throughout the course of the study.

The impoundment selected for study was C20C (134 ha) located adjacent to Banana Creek, which leads to the northern Indian River Lagoon (28 $34^{\prime}$ $\mathrm{N}, 80^{\circ} 40^{\prime} \mathrm{W}$ Figure 1). The saltmarsh vegetation is dominated by $D$. spicata and $P$. vaginatum, which are typical saltmarsh species found in the vicinity of Merritt Island. A perimeter ditch (approximately $10 \mathrm{~m}$ wide and $1 \mathrm{~m}$ deep) separates the dike from the interior of the impoundment and a major creek, "Drainout Creek", is located within the impoundment (Figure 2). Laguncularia racemosa 


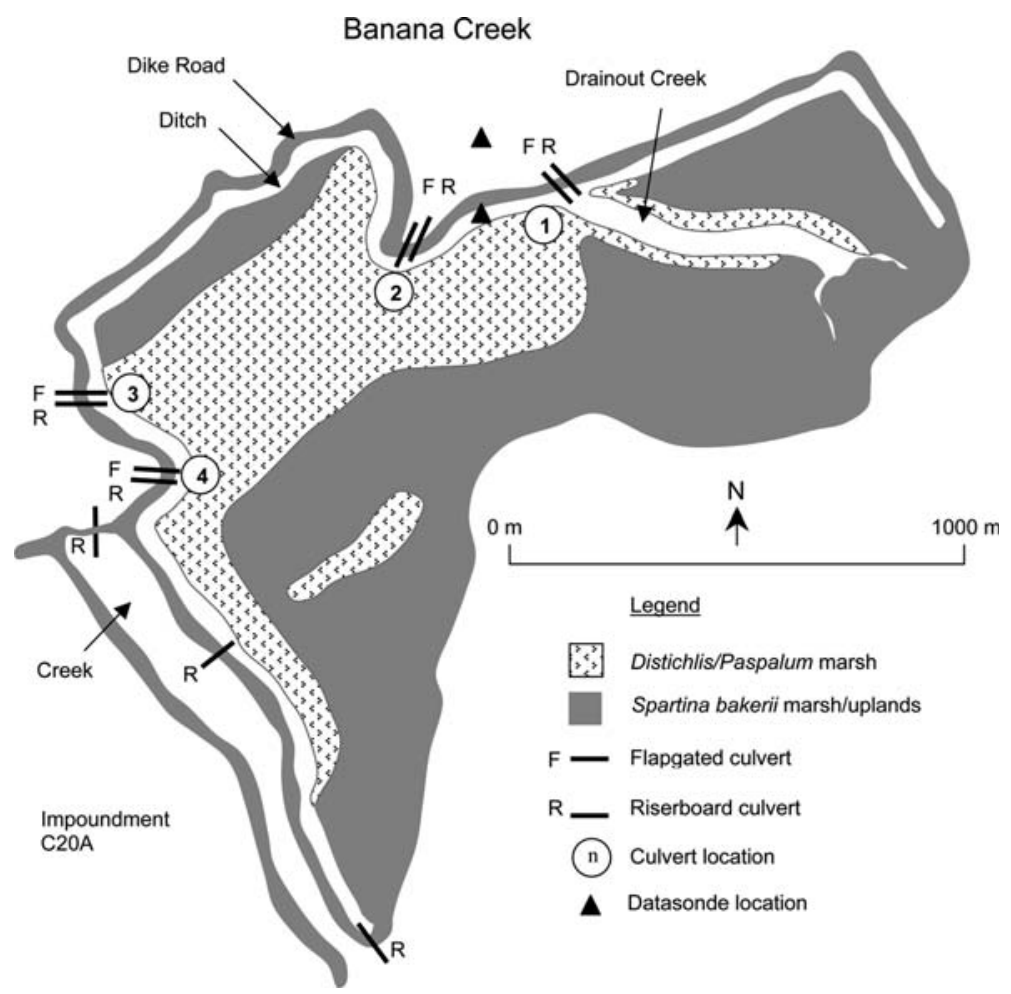

Figure 2. Map of Impoundment C20C showing vegetation types, culvert locations, and datasonde locations.

fringes the estuarine shoreline, Drainout Creek, and the perimeter ditch. In addition to live $L$. racemosa, the estuary shoreline is fringed by decaying wood from dead mangroves and a narrow band (1-3 m) of S. alterniflora often occurs seaward of live L. racemosa. Sediments are soft, especially within the perimeter ditch and Drainout Creek. Sediments along the estuary shoreline consist of firm mud within embayments and a mixture of mud and sand in areas directly adjacent to Banana Creek.

Impoundment $\mathrm{C} 20 \mathrm{C}$ is connected to the estuary by four sets of $0.91 \mathrm{~m}$ diameter culverts (Figure 2). Each set consists of one culvert with riser boards, and one culvert with a flapgate (for description of water control structures see Rey et al. 1990a). The water control structures enable resource managers to manipulate water levels within the impoundment when desired, but no manipulation was undertaken over the course of this study. The four sets of culverts connecting the impoundment to the estuary were left open (flapgate open and riserboards removed), providing estuarine communication with the impoundment.
Two additional culverts are located within the impoundment; one connects $\mathrm{C} 20 \mathrm{C}$ to an adjacent creek, and the other connects $\mathrm{C} 20 \mathrm{C}$ to a small ditch at the southern end of the impoundment (Figure 2). These two culverts were closed during the study.

\section{Water conditions}

To determine short-term and seasonal variation in water conditions within the impoundment relative to the adjacent estuary, water level (m), temperature $\left({ }^{\circ} \mathrm{C}\right)$, salinity $(\%)$, dissolved oxygen $\left(\mathrm{mg}^{-1}\right)$, and oxygen redox potential (Eh) were monitored hourly with two continuously deployed datasondes (Hydrolab ${ }^{\circledR}$ Datasonde 3); one within the impoundment and one in Banana Creek adjacent to the impoundment (Figure 2). The datasondes were calibrated prior to deployment and twice during the study period in accordance with the manufacturer's recommended procedures. Impoundment water level was recorded to within the nearest $0.3 \mathrm{~cm}$ from a permanent staff gauge 
within the impoundment. Water level measurements taken by the datasondes were corrected to correspond to water level readings on the permanent staff gauge. This was accomplished by taking the difference between datasonde water-level readings and observed readings on the impoundment staff gauge during three periods of little wind, water flow, rainfall, and water level changes. These differences were averaged to determine a correction factor. The impoundment staff gauge was later surveyed by NASA personnel, which provided a correction with respect to the 1988 National Geodetic Vertical Datum (NGVD). A few marsh draining/flooding events occurred during monthly sampling. As the marsh flooded and drained, the level at which the marsh became dry, or became flooded, was noted on the impoundment staff gauge.

\section{Fish standing stock}

Fish standing stock, fish exchange with the estuary, and predator abundance (large fish and piscivorous birds) were sampled monthly for a period of one year beginning July 2000 and ending July 2001. The monthly samples usually required one week to complete. Small fish ( $<150 \mathrm{~mm}$ total length) in the impoundment and along the adjacent estuary shoreline were quan-

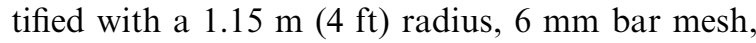
monofilament cast net. Cast nets have been used by commercial fisherman along the Indian River Lagoon to target fast-moving species such as mullet, and are often used to capture bait for recreational fishing (Schoor et al. 1995). Cast nets have been used in research to collect fish in shallow-water canals (Meador and Kelso 1990), to target specific fish species (Taylor and Gerking 1978), and to supplement impoundment perimeter ditch collections (e.g., Gilmore et al. 1982; Klassen 1998). Gear testing comparisons among cast nets, seines, and throw traps within an impoundment perimeter ditch found cast nets to be less efficient than the other gears, but the species composition and size ranges of fish were comparable to seines (P. Stevens, manuscript in submission). The major advantage of using a cast net in the saltmarsh impoundments was that it could be easily deployed by casting from the shoreline or from a small boat, thereby allowing the perimeter ditches and marsh creeks to be sampled with a random design, rather than with fixed stations that are necessary when sampling impoundments with seines (Gilmore et al. 1982; McLaughlin 1982; Rey et al. 1990; Karlen 1991; Lin and Beal 1995; Klassen 1998; Taylor et al. 1998; Faunce and Paperno 1999; Poulakis et al. 2002). A random design was an important aspect of the study because one of the objectives was to compare fish densities among habitats associated with saltmarsh impoundments. The diameter and mesh size of the cast net were chosen because the small diameter was manageable to throw, thereby reducing variation in deployment area, and the mesh size was appropriate for capturing saltmarsh fishes.

The cast net was deployed among the primary habitats associated with both transient juvenile fish and resident nekton. The areas sampled with the cast net were the perimeter ditch (ca. $1 \mathrm{~m}$ depth), and creek (ca. $1 \mathrm{~m}$ depth). The estuary shoreline $(<1 \mathrm{~m}$ depth) was also sampled for comparison with the impoundment habitats. The estuary shoreline was sampled along the dike within at least $1 \mathrm{~m}$ of the emergent shoreline vegetation and often within low-density S. alterniflora. The seasonally flooded marsh surface $(<0.5 \mathrm{~m}$ depth) was sampled during July 2000 (the onset of marsh flooding), and October 2000 (the time of seasonally high water). The marsh surface consisted of consolidated mud substrate, emergent vegetation, open water ponds, and small potholes (2-3 m diameter). The marsh surface was sampled in open water areas near emergent vegetation and within small potholes. Deeper pools within the marsh were also sampled during January 2001 (after water had receded from the marsh) to measure the density of any fish remaining in ponded water.

A pilot study conducted during March 2000 determined that a minimum of 14 cast net deployments were needed to detect a statistical difference between the mean numbers of fish from each habitat $(\alpha=0.05, \beta=0.90$; Sokal and Rohlf 1995). Each habitat type (Drainout Creek, perimeter ditch, marsh surface, and estuary shoreline) was mapped using aerial photography (US Geological Survey, 1995 aerial photography). The 14 cast-net deployment stations along the estuary shoreline were selected by randomly choosing among 136 sampling points spaced $16 \mathrm{~m}$ 
apart along the perimeter dike. The 14 stations in the perimeter ditch were selected by randomly choosing from among 98 sampling points (a $615 \mathrm{~m}$ segment of the perimeter ditch was excluded due to inaccessibility) spaced $16 \mathrm{~m}$ apart along the centerline of the perimeter ditch. For the Drainout Creek sampling, 14 points were selected from among 55 potential sampling points (30 $\mathrm{m}$ apart). For the marsh surface sampling, 14 points were chosen in areas of low vegetation density and depth of at least $10 \mathrm{~cm}$ (marsh/shallow ponds; Figure 2).

A small jon boat equipped with an electric trolling motor was used to access the perimeter ditch, creek, and estuary shoreline for cast net deployment. For the estuary shoreline sampling, the cast net was deployed as close to the shoreline as possible without fouling the net in wood debris or overhanging trees. For perimeter ditch sampling, a coin was tossed prior to each cast net deployment to determine whether to cast the net along the edge or near the center of the ditch. Collected fish were identified to species, counted, measured ( $\mathrm{mm}$ total length), and released. Some fish were retained for identification or length-weight analysis. Cast nets occasionally captured large fish (>150 mm total length), which were excluded from the cast net analysis because they were better represented in gill net catches (see piscivores section). Cast net sampling data were reported as fish $\mathrm{m}^{-2}$ (mean $( \pm \mathrm{SD})$ deployment area of cast nets was $2.8 \pm 0.2 \mathrm{~m}^{-2}$ ). Weights $(\mathrm{g})$ were determined from length-weight relationships.

\section{Fish exchange with the estuary}

Culverts isolated the ingress and egress of fish to specific pathways, which provided an opportunity to quantify fish movements between coastal wetlands and the adjacent estuary using culvert traps. Culvert traps are oversized minnow traps with a dividing screen placed at the center so that the direction of movement of captured fish can be determined (Gilmore et al. 1982). A modified version of the stainless steel culvert trap used by Gilmore et al. (1982), Rey et al. (1990a), and Taylor et al. (1998) was constructed using typical fish trap material (plastic coated wire and $0.25 \mathrm{~cm}$ bar mesh $\left.\operatorname{Vexar}{ }^{\circledR}\right)$. The traps were $80 \mathrm{~cm}$ in diameter, which was slightly smaller than the diameter of the culverts $(91 \mathrm{~cm}$ diameter) to account for fouling organism growth inside the culverts. The opening of the culvert trap was $42 \mathrm{~cm}$ high $\times 8 \mathrm{~cm}$ wide, and the typical gap between the culvert trap and the sides of the fouled culvert walls was $2 \mathrm{~cm}$. Four culvert traps were available to document fish movements.

Culvert trap sampling was conducted for four days and four nights continuously each month for one year beginning July 2000 and ending June 2001. One culvert trap was placed at each culvert location (culvert locations 1-4; see Figure 2). Two culverts are present at each culvert location, but only one was sampled with the trap, the other remained unobstructed. Captured fish within the culvert traps were removed twice per day (early morning, and late afternoon) except if detrital fouling necessitated more frequent processing to keep the traps clear. Water flow through the culverts was measured with a flow meter during each nekton collection before and after the culvert trap was installed inside the culvert. Collected fish were identified to species, and their direction of travel recorded. Fish were counted, measured ( $\mathrm{mm}$ total length), and released in the direction they were traveling. Weights $(\mathrm{g})$ were determined from length-weight relationships. Culvert trap catches were reported as fish culvert ${ }^{-1} \mathrm{~h}^{-1}$.

A separate study was conducted during July 2001 to determine if fished and adjacent unfished culverts differed in fish passage rates. There is one flapgate and one riserboard culvert at each culvert location (see Figure 2), but only one was fished with a culvert trap. When a culvert trap was added to a culvert, the current through the culvert was reduced by about $50 \%$, while current in the adjacent culvert (unfished) remained the same. To simulate this condition, both culverts at a location were fished simultaneously. One trap was fitted with an additional dividing screen to reduce the flow by $50 \%$ relative to the adjacent culvert. After fishing the culverts for two days and two nights, the trap with the added dividing screen and the unmodified trap were switched, and then fished for an additional two days and two nights. This test was repeated at each of two culvert locations (culvert location 1 and 4; see Figure 2). 


\section{Piscivores}

Large fish ( $>150 \mathrm{~mm}$ total length) within impoundments and the adjacent estuary were sampled with gill nets to estimate the abundance of potential predators of resident and juvenile transient nekton. Gill nets, $38 \mathrm{~mm}$ (1.5 in.) monofilament bar mesh, were deployed at fixed stations where the nets could be easily set, observed, and retrieved (typically near culvert locations). The nets were $1.2 \mathrm{~m}$ deep, and the depth of the water in which they were fished ranged from 0.5 to $1 \mathrm{~m}$. Gill nets were set in the impoundment ditch (four $10 \mathrm{~m}$ net sections), the impoundment creek (one $30 \mathrm{~m}$ net), and the estuary shoreline (two $30 \mathrm{~m}$ nets). The nets were set perpendicular to shorelines. Each net was deployed one day each month for 2-3 h between 1700 and 2100 Eastern Standard Time, and checked for fish every $30 \mathrm{~min}$ during deployment. The perimeter ditch and creek gill nets were deployed, checked for fish, and retrieved using a small jon boat to minimize disturbance to the soft sediments. The shoreline gill nets were deployed, checked for fish, and retrieved by wading along the gill net. Piscivorous fish abundance was reported as catch per unit effort (fish 10 $\mathrm{m} \mathrm{net}^{-1} \mathrm{~h}^{-1}$ ). Catch per unit effort was standardized to a $10 \mathrm{~m}$ net length by dividing the fish catch by the number of $10 \mathrm{~m}$ sections fished $(10 \mathrm{~m}$ of net deployed at each ditch location, and $30 \mathrm{~m}$ (i.e., three $10 \mathrm{~m}$ sections) of net deployed at the creek and each estuary shoreline location).

Fish greater than about $800 \mathrm{~mm}$ total length such as Megalops atlanticus Valenciennes and Pogonias cromis (Linnaeus) broke through the $38 \mathrm{~mm}$ bar mesh monofilament nets during the estuary shoreline sets and were not assessed by this method. Attempts to use larger $50 \mathrm{~mm}$ bar mesh nets were thwarted by the occurrence of large alligators, which broke through the $38 \mathrm{~mm}$ bar mesh, but would entangle in the larger $50 \mathrm{~mm}$ bar mesh. All uninjured fish captured by gill net were fin-clipped, measured (mm total length), and released. Fish injured during gill net capture were frozen whole and returned to the laboratory for stomach content study or length-weight analysis.

Other potential predators of resident and juvenile transient nekton were piscivorous birds such as wading birds and diving birds. Piscivorous bird abundance was determined by visual surveys, consistent with methods used to monitor bird abundance within the refuge (E. Stolen, Dynamac Corporation, personal communication). Piscivorous birds within the impoundment were identified and counted by visual survey taken from the dike road between 0700 and 0900 Eastern Standard Time twice each month. Birds along the estuary shoreline adjacent to the impoundment (within $20 \mathrm{~m}$ of the dike) were counted separately. Piscivorous bird abundance was reported as birds impoundment ${ }^{-1} \mathrm{~d}^{-1}$. Weights were determined from published estimates.

\section{Nomenclature and analyses}

Two components of aquatic communities are recognized by nekton studies conducted in coastal wetlands: resident (those species that can complete their life history within marshes), and transient (those species that use marshes during some portion of their life cycle either as nursery habitat for juveniles or as regular feeding areas for adults). A third group, incidental species, was used to refer to those species that are associated with seagrasses and other open estuary habitats, but may occur in saltmarsh impoundments either by accident or as a minor extension to their primary habitat. Nomenclature of saltmarsh vegetation follows Duncan and Duncan (1987), nomenclature of birds follows Terres (1980), and nomenclature of fishes follows Robins et al. (1991).

Fish standing stock, net fish ingress, piscivorous fish, and piscivorous bird results were plotted, and differences among months were analyzed graphically. Average monthly impoundment water level was included with the above plots because it has been shown to drive saltmarsh fish ecology (e.g., Rozas 1995; Poulakis et al. 2002). Standing stock (cast net) data were log transformed and months pooled. Comparisons of fish density among the various habitats sampled (perimeter ditch, creek, and estuary shoreline) were then performed using analysis of variance. Significant differences were analyzed further by Tukey's pairwise comparisons. These statistical analyses were performed for resident and transient fish separately (number and biomass). Length frequency plots were constructed for species where more than 100 individuals were collected. All statistical analyses were performed with Systat 8.0 (SPSS) software. 


\section{Results}

\section{Water conditions}

Water level during the study period was lowest during late winter/early spring and highest during fall (Figure 3). During summer, water level oscillated near marsh elevation, periodically flooding the marsh for one to two weeks. The marsh was continuously flooded beginning in July 2000 and ending in December 2000 (6 months). Over the course of the study, water level ranged between 0.2 and $0.8 \mathrm{~m}$ NGVD. Maximum water temperature during summer exceeded $35^{\circ} \mathrm{C}$, and minimum temperature in winter fell below $10{ }^{\circ} \mathrm{C}$ (Figure 3). Water temperature varied diurnally, with maximum temperatures occurring late in the day. Salinity fluctuated dramatically, particularly during spring through fall (Figure 3). A series of low salinity pulses occurred near the end of the study (May through July 2001). Minimum salinities during the record were about $10 \%$, and maximum salinities exceeded $40 \%$. Dissolved oxygen and redox potential were highest during fall and winter and lowest during summer. Both dissolved oxygen and redox potential varied diurnally, with maximum daily dissolved oxygen $\left(\sim 5 \mathrm{mg} \mathrm{l}^{-1}\right)$ and redox potential $(\sim 400 \mathrm{mV})$ observed late in the day, and minimum values (near $0 \mathrm{mg} \mathrm{l}^{-1}$ and $<100 \mathrm{mV}$ ) observed during morning hours. Thus, overall diurnal pattern was minimum dissolved oxygen and redox potential each morning, which represent the most limiting combination of water conditions with respect to nekton. These limiting conditions, however, only occurred for a few hours each day (ca. 0600-0900).

During January 2001, a widespread fish kill occurred in Banana Creek following a severe freeze. Water temperature dropped below $8^{\circ} \mathrm{C}$ on January 1 and remained cold $\left(<2{ }^{\circ} \mathrm{C}\right)$ for several days. Water temperature again dropped below $12^{\circ} \mathrm{C}$ during late January. Dead fish observed along the estuary shoreline adjacent to the study site included hundreds of Arius felis (Linnaeus), four Caranx hippos (Linnaeus), three M. atlanticus, and two Mugil cephalus Linnaeus. Several dozen Poecilia latipinna (Lesueur) were found floating dead in Drainout Creek and the perimeter ditch. Fish kills were not observed in the study area at any other time.
Average water flow through culverts at Impoundment C20C measured during culvert trap sampling varied among months. Average water flow was into the impoundment through culverts at $10-30 \mathrm{~cm} \mathrm{~s}^{-1}$ at the onset of marsh flooding in July 2000 and again during a flooding event in March 2001. Water was moving out of the impoundment through culverts at about $10 \mathrm{~cm} \mathrm{~s}^{-1}$ during September and October 2000, and April, May, and June 2001.

\section{Fish standing stock}

The fishes collected from the marsh surface by cast net in July and October 2000, and January 2001 were primarily resident species - Cyprinodon variegatus Lacepède $(n=341), \quad P$. latipinna $(n=158)$, Lucania parva (Baird and Girard) $(n=7)$, Gambusia holbrooki Girard $(n=5)$, Fundulus grandis Baird and Girard $(n=4)$, Menidia spp. $(n=4)$, and Fundulus confluentus Goode and Bean $(n=3)$. One transient species, M. cephalus $(n=23)$, was collected.

The most common species caught by cast net in the impoundment ditch and creek were resident fishes such as $P$. latipinna, $G$. holbrooki, and $C$. variegatus (Table 1). All dominant species were most abundant during winter months. Along the estuary shoreline, Floridichthys carpio (Günther), ranked among the most common species in addition to resident fishes. Mugil cephalus, a transient species, ranked among the five to six most common fishes both in the saltmarsh and along the shoreline. Other transient species, although less common, included Leiostomus xanthurus Lacepède, Elops saurus Linnaeus, and Strongylura notata (Poey).

Resident fish accounted for $95 \%$ of the numerical density for all fish caught by cast net in the impoundment and $75 \%$ of the biomass. In general, fish density in the impoundment ditch and creek was low during July through November when the marsh was flooded (Figures $4 \mathrm{~b}$ and 5b). Impoundment fish densities increased dramatically in December through February when water receded from the marsh surface $(76 \%$ of the fish during this period were collected from the impoundment ditch). Less pronounced peaks in abundance occurred during May and July and were attributable to high numerical fish density in 

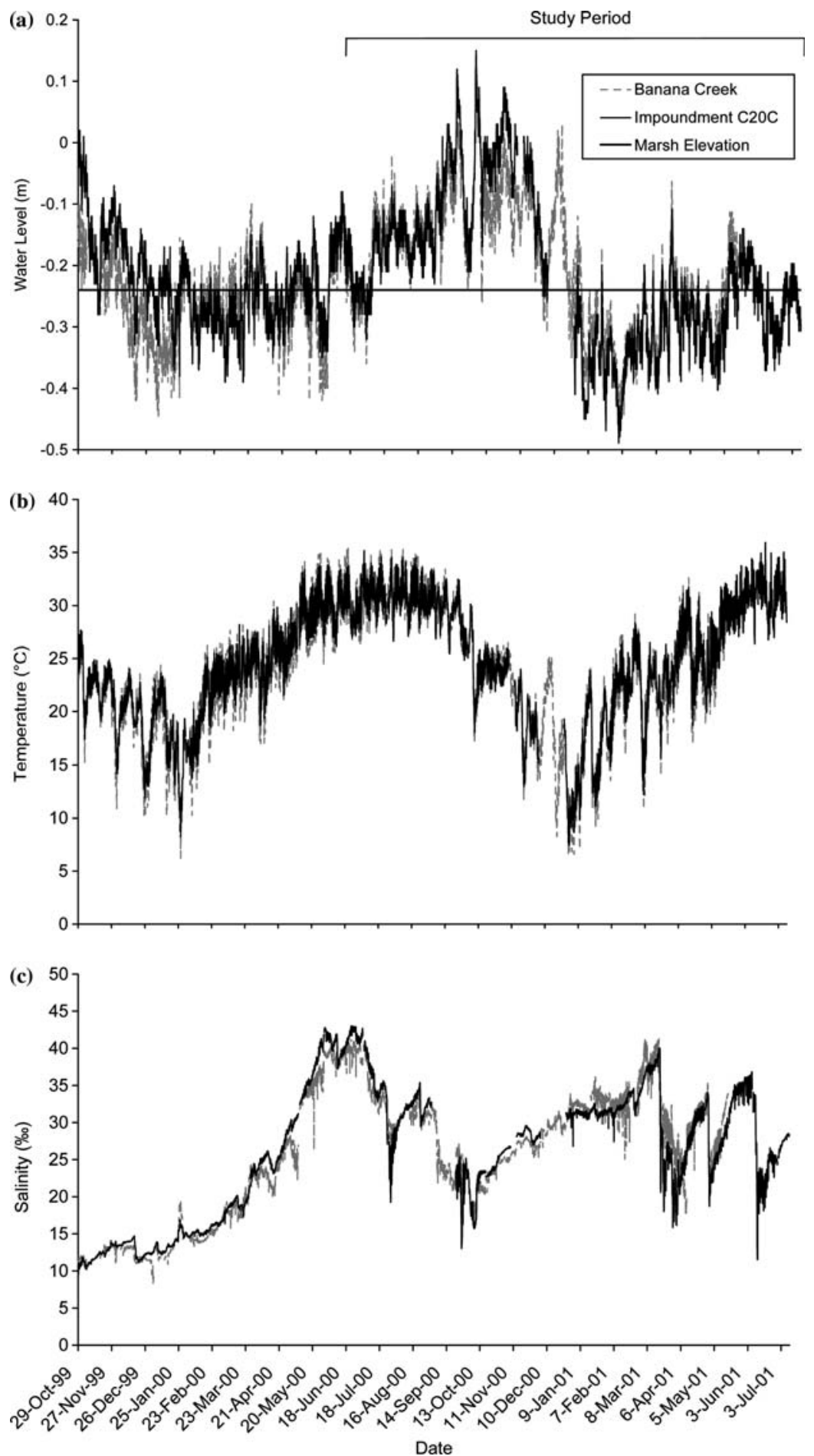

Figure 3. Water level, temperature, and salinity during 21 months, including study period, from datasondes that continuously measured water conditions hourly in Impoundment C20C and Banana Creek. 
Table 1. Fishes and invertebrates (no.) captured by cast net within ditch and creek in Impoundment C20C and along the adjacent estuary shoreline, and those captured in ingress and egress portions of culvert traps $(n=$ number of cast deployments or hrs traps fished).

\begin{tabular}{|c|c|c|c|c|c|c|}
\hline \multirow[t]{2}{*}{ Species } & & \multirow[t]{2}{*}{ Common name } & \multicolumn{2}{|l|}{ Cast net } & \multicolumn{2}{|l|}{ Culvert trap } \\
\hline & & & $\begin{array}{l}\text { Impoundment } \\
(n=364)\end{array}$ & $\begin{array}{l}\text { Shoreline } \\
(n=182)\end{array}$ & $\begin{array}{l}\text { Ingress } \\
(n=4124)\end{array}$ & $\begin{array}{l}\text { Egress } \\
(n=4124)\end{array}$ \\
\hline Alpheus heterochaelis & I & Snapping shrimp & & & 23 & 63 \\
\hline Anchoa mitchilli & I & Bay anchovy & 13 & 11 & 12 & 35 \\
\hline Brevoortia smithi & $\mathrm{I}$ & Yellowfin menhaden & & 4 & & \\
\hline Callinectes sapidus & $\mathrm{T}$ & Blue crab & & & & 2 \\
\hline Cynoscion nebulosus & $\mathrm{T}$ & Spotted seatrout & & 1 & 4 & 12 \\
\hline Cyprinodon variegatus & $\mathrm{R}$ & Sheepshead minnow & 1,542 & 228 & 3,556 & 8,792 \\
\hline Elops saurus & $\mathrm{T}$ & Ladyfish & 6 & 1 & & 2 \\
\hline Eucinostomus spp. & I & Mojarras & & 1 & 4 & 3 \\
\hline Floridichthys carpio & I & Goldspotted killifish & & 119 & 7 & 7 \\
\hline Fundulus confluentus & $\mathrm{R}$ & Marsh killifish & 22 & & 8 & 11 \\
\hline Fundulus grandis & $\mathrm{R}$ & Gulf killifish & 50 & 6 & 64 & 238 \\
\hline Gambusia holbrooki & $\mathrm{R}$ & Eastern mosquitofish & 1,583 & 27 & 1,235 & 840 \\
\hline Gobiosoma bosc & $\mathrm{I}$ & Naked goby & & 1 & 31 & 23 \\
\hline Gobiosoma robustum & I & Code goby & & 1 & 47 & 30 \\
\hline Hippocampus reidi & I & Longsnout seahorse & & 1 & & \\
\hline Jordanella floridae & $\mathrm{R}$ & Flagfish & 1 & & 1 & \\
\hline Leiostomus xanthurus & $\mathrm{T}$ & Spot & 9 & & 9 & 175 \\
\hline Lucania parva & $\mathrm{R}$ & Rainwater killifish & 119 & 85 & 2,979 & 1,711 \\
\hline Menidia spp. & $\mathrm{R}$ & Silversides & 155 & 8 & 3,140 & 3,532 \\
\hline Microgobius gulosus & $\mathrm{I}$ & Clown goby & 1 & 3 & 19 & 30 \\
\hline Mugil cephalus & $\mathrm{T}$ & Striped mullet & 343 & 36 & 288 & 478 \\
\hline Palaemonetes pugio & $\mathrm{R}$ & Grass shrimp & 85 & 87 & 5,999 & 2,952 \\
\hline Poecilia latipinna & $\mathrm{R}$ & Sailfin molly & 3,318 & 259 & 11,386 & 8,268 \\
\hline Sciaenops ocellatus & $\mathrm{T}$ & Red drum & & & 3 & \\
\hline Strongylura notata & $\mathrm{T}$ & Redfin needlefish & 3 & & 37 & 7 \\
\hline Syngnathus scovelli & $\mathrm{I}$ & Gulf pipefish & & 9 & 1 & 1 \\
\hline Trinectes maculatus & $\mathrm{T}$ & Hogchoker & & & 20 & 30 \\
\hline Residents - R & & & 6,875 & & 28,368 & 24,635 \\
\hline Transients $-\mathrm{T}$ & & & 361 & & 361 & 2,417 \\
\hline Incidentals - I & & & 14 & & 147 & 197 \\
\hline Total & & & 7,250 & 888 & 28,876 & 27,249 \\
\hline
\end{tabular}

the impoundment creek $(91 \%$ of the fish during May and July were collected from the impoundment creek). Comparisons among impoundment and shoreline habitats revealed that resident fish density in the impoundment creek and the ditch (pooling months) were 4.1 and 6.6 fish $^{-2}$ higher, respectively, than along the shoreline $(p=0.009,0.0006$; Tukey's pairwise comparisons). Transient fish densities in the impoundment creek and ditch (pooling months) were 0.2 and 0.3 fish $\mathrm{m}^{-2}$ higher, respectively, than along the shoreline ( $p=0.02,0.005$; Tukey's pairwise comparisons).

Dominant fishes on the marsh surface, $C$. variegatus and $P$. latipinna, displayed the same size distribution in October as those caught when the marsh first flooded in July (90 and $86 \%$ of C. variegatus were between 35 and $45 \mathrm{~mm}$ total length during July and October, respectively, and 89 and $96 \%$ of $P$. latipinna were between 31 through $50 \mathrm{~mm}$ total length during July and October, respectively). As water levels receded in December, $C$. variegatus left in the remaining ponds on the marsh were about $10 \mathrm{~mm}$ total length smaller than those present when the marsh was completely flooded $(85 \%$ were between 23 and $36 \mathrm{~mm}$ total length), and $P$. latipinna were about $20 \mathrm{~mm}$ total length smaller $(100 \%$ were between 19 and $26 \mathrm{~mm}$ total length).

Fishes commonly collected from the impoundment creek and ditch grew during the study period. 

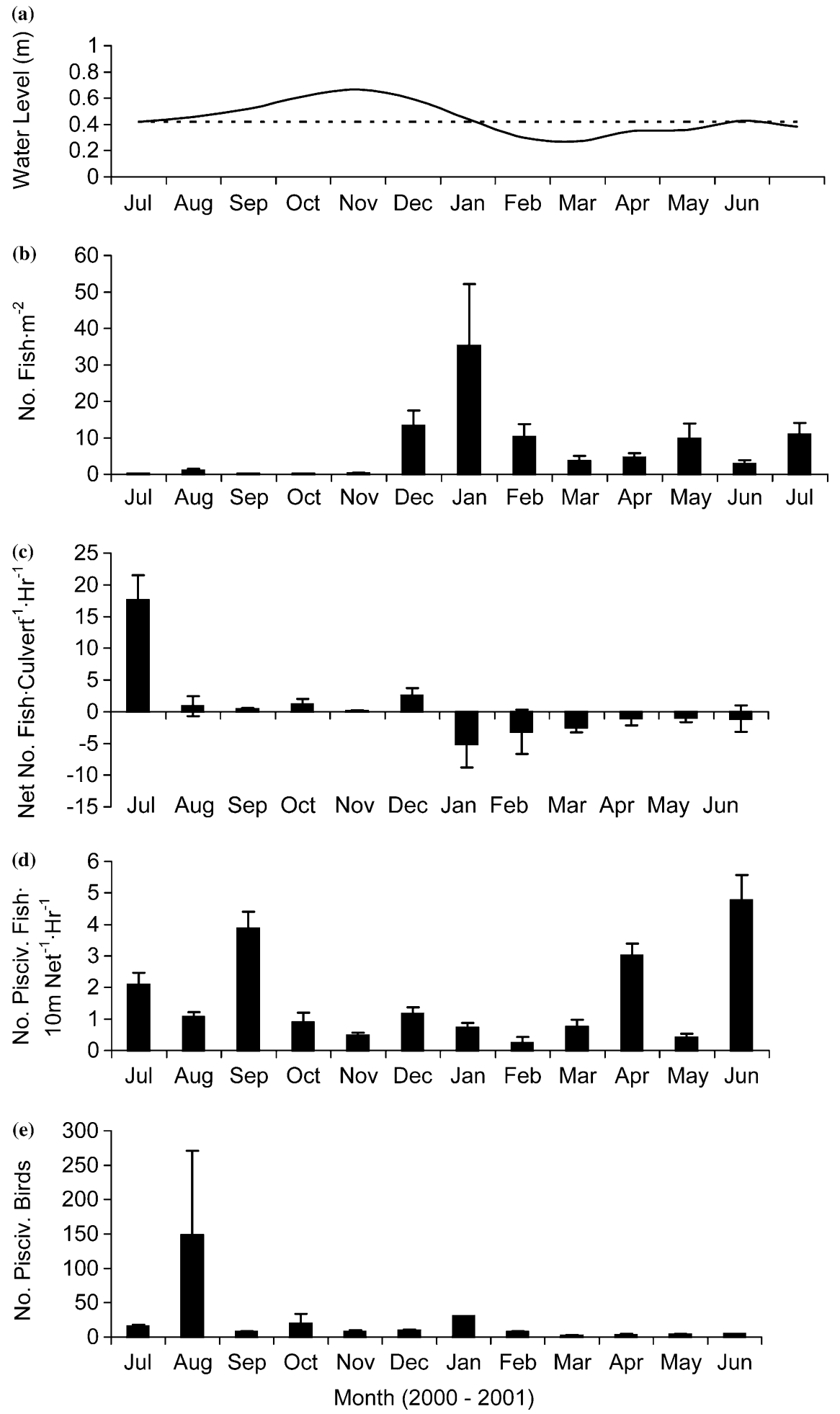

Figure 4. Average monthly water level (a) (dotted line indicates marsh elevation), fish standing stock (b), net fish exchange (c) (negative indicates net movement out of impoundment), large piscivorous fish catch per unit effort (d), and piscivorous bird abundance (e) by number. Error bars represent standard error. 

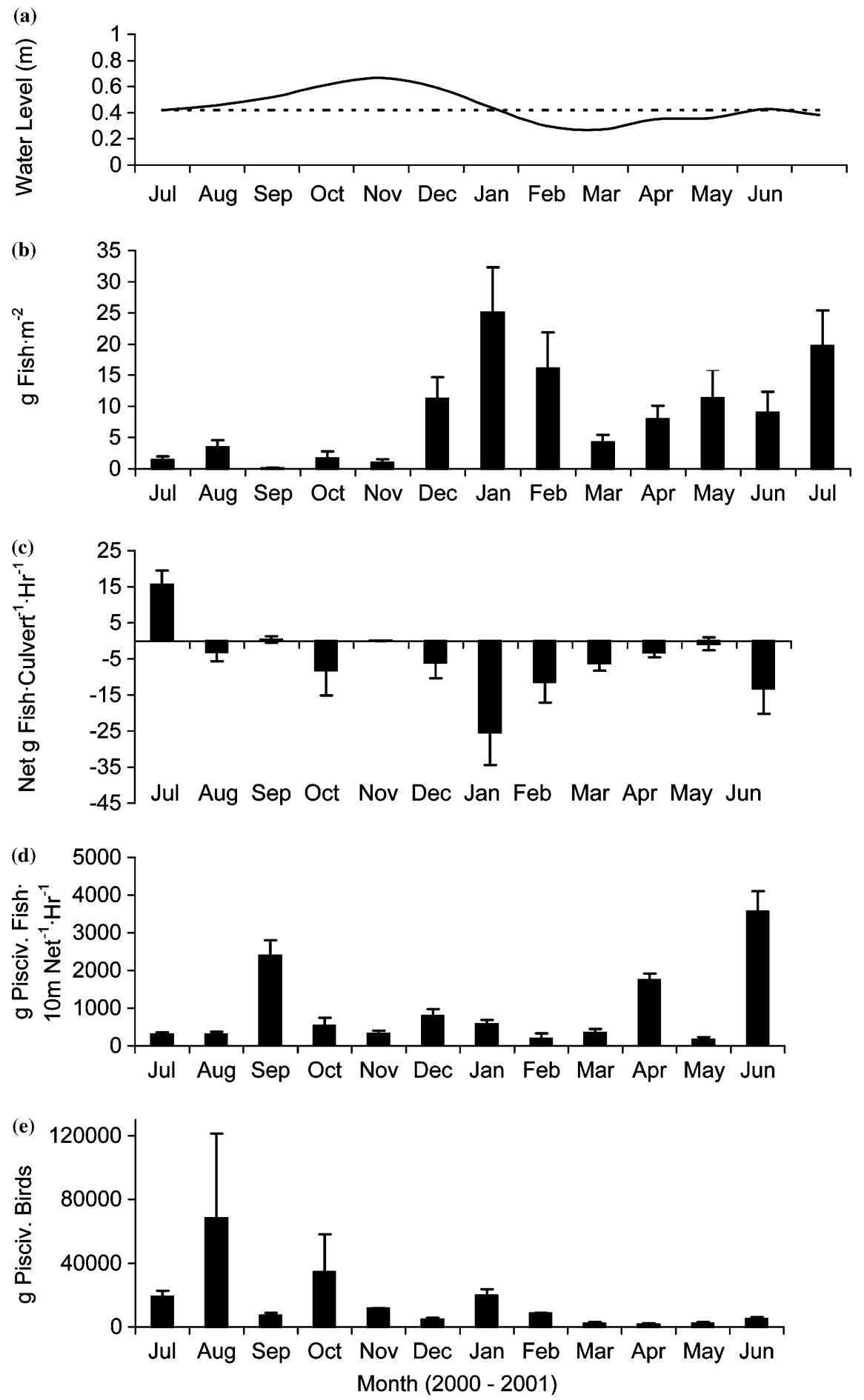

Figure 5. Average monthly water level (a) (dotted line indicates marsh elevation), fish standing stock (b), net fish exchange (c) (negative indicates net movement out of impoundment), large piscivorous fish catch per unit effort (d), and piscivorous bird abundance (e) by biomass. Error bars represent standard error. 
Sizes of common impoundment fishes, except $M$. cephalus, were evenly distributed during July through November, smallest during December through February, and were highly skewed towards larger fish during June and July (size ranges of C. variegatus, P. latipinna, G. holbrooki, and Menidia spp. were 17-60 $\mathrm{mm}$ total length, 13$68 \mathrm{~mm}$ total length, $13-38 \mathrm{~mm}$ total length, and 11-95 mm total length, respectively). Sizes of $M$. cephalus were smallest during March through May and got progressively larger, with the largest occurring during December through February (size range of $M$. cephalus was $21-300 \mathrm{~mm}$ total length). Size frequency distributions for $L$. parva were evenly distributed throughout the study (size range of $L$. parva was $23-40 \mathrm{~mm}$ total length).

\section{Fish exchange with the estuary}

The comparison of fish passage between adjacent culverts (one culvert with a reduced flow relative to the other) (Table 2), found no significant differences in total fish catch numerically $(p=0.20$; Kruskal-Wallis one-way ANOVA) or by biomass $(p=0.14 ; \quad$ Kruskal-Wallis one-way ANOVA) ( $n=14$ pairs). Small $(<150 \mathrm{~mm}$ total length), numerically dominant fishes caught in culvert traps were resident species such as $C$. variegatus, $P$. latipinna, Menidia spp., Palaemonetes pugio Holthius, L. parva, and G. holbrooki (Table 1). The culvert trap collections included a greater number of species than those from the cast net. Many of these species were incidental with respect to use of marshes as primary habitat, but some small transient species were caught also. These include important resource species such as Sciaenops ocellatus (Linnaeus) and Cynoscion nebulosus (Cuvier).

Resident fish accounted for $97 \%$ of all fish caught by culvert trap and $80 \%$ of the biomass. At the onset of marsh flooding in July 2000, net fish ingress occurred (July in Figures $4 \mathrm{c}$ and $5 \mathrm{c}$ ). Schools of P. latipinna, verified by cast net, were observed moving to the east along the Banana Creek shoreline. This species was also the most abundant caught in culvert traps entering the saltmarsh during the same period. During fall and winter, net fish ingress was low (August through November). Following the recession of water level in late winter/early spring, and subsequent fish concentration into impoundment ditches and creeks, a marked egress of fish from the impoundment to the estuary ensued. Over the course of the study, 6\% more fish entered the impoundment then left, but over $200 \%$ more fish biomass left than entered (Table 3). Number and biomass of fishes that entered and left were roughly similar for P. latipinna, Menidia spp., G. holbrooki, and L. parva. For P. pugio, however, more entered than left, and for C. variegatus and Fundulus spp. more left than entered. For example, 2.5 times as many, and 4.2 times the biomass of C. variegatus left the impoundment then entered. For F. grandis, 3.7 times as many, and 8.5 times the biomass, left than entered. Large piscivorous fish ( $>150 \mathrm{~mm}$ total length), not included in the above analysis, were also captured in culverts (91 E. saurus, eight $S$. ocellatus, four C. nebulosus, and two Lepisosteus platyrhincus DeKay).

\section{Piscivores}

More large piscivorous fishes were captured along the estuary shoreline than within the impoundment, although the dominant fishes along the estuary shoreline were nonpiscivorous (i.e., M. cephalus and A. felis) (Table 4). Large piscivorous transients (i.e., S. ocellatus, E. saurus, and $C$. nebulosus) were present in impoundment gill nets primarily during fall months, and

Table 2. Comparison of fish catch (no. and $\mathrm{g}$ fish $\operatorname{trap}^{-1} \mathrm{~h}^{-1}$ ) between reduced flow and unmodified culvert traps.

\begin{tabular}{llllll}
\hline Habitat & Number & & & Biomass $(\mathrm{g})$ & \\
\cline { 2 - 3 } \cline { 5 - 6 } & Unmodified trap & Reduced flow trap & & Unmodified trap & Reduced flow trap \\
\hline Average & -1.5 & -4.2 & 3.1 & -1.0 & 1.2 \\
SE & 1.5 & 3.2 & 5.0 \\
\hline
\end{tabular}

Values shown are means for each trap type ( $n=167 \mathrm{~h}$ fished for each trap type). 
Table 3. Exchange of resident marsh fishes and invertebrates (no. and g fish) in Impoundment C20C over the study period $(n=4124$ traps fished).

\begin{tabular}{|c|c|c|c|c|c|c|}
\hline \multirow[t]{2}{*}{ Species } & \multicolumn{3}{|l|}{ Number } & \multicolumn{3}{|c|}{ Biomass (g) } \\
\hline & Egress (no.) & Ingress (no.) & Egress/ingress (no.) & Egress (g) & Ingress $(\mathrm{g})$ & Egress/ingress (g) \\
\hline Cyprinodon variegatus & 8,792 & 3,556 & 2.47 & 19,998 & 4,711 & 4.25 \\
\hline Fundulus grandis & 238 & 64 & 3.72 & 3,902 & 459 & 8.51 \\
\hline Menidia spp. & 3,532 & 3,140 & 1.12 & 5,393 & 3,662 & 1.47 \\
\hline Fundulus confluentus & 11 & 8 & 1.38 & 39 & 15 & 2.53 \\
\hline Gambusia holbrooki & 840 & 1,235 & 0.68 & 351 & 525 & 0.67 \\
\hline Palaemonetes pugio & 2,952 & 5,999 & 0.49 & 871 & 1,761 & 0.49 \\
\hline Lucania parva & 1,711 & 2,979 & 0.57 & 2,018 & 3,105 & 0.65 \\
\hline Poecilia latipinna & 8,268 & 11,386 & 0.73 & 9,636 & 11,234 & 0.86 \\
\hline Other fish & 905 & 509 & 1.78 & 15,029 & 2,217 & 6.78 \\
\hline Total & 27,249 & 28,876 & 0.94 & 57,236 & 27,687 & 2.07 \\
\hline
\end{tabular}

L. platyrhincus were most abundant during April and June, coinciding with periods of low salinity. These species account for peaks in piscivorous fish catch per unit effort that occurred in July, September, April, and June (Figures $4 \mathrm{~d}$ and $5 \mathrm{~d}$ ). During low water level in December through March, piscivorous fish catch per unit effort was low despite the high density of small fish in the impoundment.

During the entire study period, 210 large piscivorous fish caught in impoundment gill nets and 67 piscivorous fish caught in estuary shoreline gill nets were fin-clipped and released. Despite a high number of marked fish, particularly in the impoundment, only four L. platyrhincus and one C. nebulosus were recaptured. The four L. platyrhincus were both marked and recaptured within the impoundment, and the $C$. nebulosus was marked in the impoundment and recaptured along the estuary shoreline. Twenty-one and $41 \%$ of large piscivorous fish caught in the impoundment and shoreline gill nets, respectively, died. Many of the stomachs of fish that died in gill nets were empty (53\% of impoundment fish and $37 \%$ of shoreline fish). Of the impoundment-captured fish that had full stomachs, frequency of occurrence (no.) of species found in stomachs included unidentifiable fish (12), Alpheus spp. (4), P. pugio (4), P. latipinna (2), C. variegatus (1), Menidia spp. (2), and G. holbrooki (2). Benthic invertebrates (10), and various fishes (15) occurred in stomachs of shoreline-captured fish.

The most common bird species in the impoundment, Egretta thula (Molina), was absent from the estuary shoreline (Table 4). Both piscivorous and nonpiscivorous birds were more abundant in the impoundment relative to the estuary shoreline. An aggregation of over 250 birds (most of which were E. thula) was present within the impoundment upon our arrival in August and persisted for an additional four days before dispersing. This aggregation followed the dramatic fish ingress into the impoundment at the onset of marsh flooding (Figures $4 \mathrm{e}$ and 5e). Piscivorous birds were abundant in January along the impoundment creek and ditches as water level receded from the marsh and resident fish concentrated into deeper impoundment habitats.

\section{Discussion}

\section{Water conditions}

Fish kills resulting from low oxygen level occasionally occur during summer in the northern Indian River Lagoon, particularly in areas sheltered from wind or following several days of cloudiness when respiration exceeds photosynthesis for extended periods (J. Egan, Marine Resources Council, personal communication). Despite low dissolved oxygen and redox potential in Banana Creek and Impoundment C20C, particularly during morning hours, fish were present among impoundment and estuary shoreline habitats. No dead fish were observed during the study (except freeze-killed fish), even during summer when dissolved oxygen and redox potential reached their lowest minimum levels. 
Table 4. Fishes (no.) captured by gill net within Impoundment C20C and adjacent Banana Creek shoreline, and birds counted during census ( $n=169 h, 10 \mathrm{~m}$ nets fished in both impoundment and along shoreline, and $n=2$ bird counts each month totaling 24 counts).

\begin{tabular}{|c|c|c|c|}
\hline Species & Common name & Impoundment & Shoreline \\
\hline \multicolumn{4}{|l|}{ Fish } \\
\hline Arius felis & Hardhead catfish & 1 & 158 \\
\hline Bairdiella chrysoura & Silver perch & & 1 \\
\hline Caranx hippos* & Crevalle jack & & 9 \\
\hline Centropomis undecimalis* & Common snook & & 2 \\
\hline Cynoscion nebulosus* & Spotted seatrout & 34 & 11 \\
\hline Dasyatis sabina & Atlantic stingray & & 16 \\
\hline Diapterus auratus & Irish pompano & & 2 \\
\hline Dorosoma cepedianum & Gizzard shad & & 1 \\
\hline Elops saurus* ${ }^{*}$ & Ladyfish & 24 & 28 \\
\hline Leiostomus xanthurus & Spot & 15 & 8 \\
\hline Lepisosteus platyrhincus* & Florida gar & 167 & 7 \\
\hline Megalops atlanticus* & Tarpon & & 3 \\
\hline Micropogonias undulatus & Atlantic croaker & & 1 \\
\hline Mugil cephalus & Striped mullet & 43 & 70 \\
\hline Pogonias cromis* & Black drum & & 2 \\
\hline Sciaenops ocellatus* & Red drum & 40 & 30 \\
\hline Sphoeroides nephelus & Southern puffer & & 1 \\
\hline Piscivorous & & 265 & 223 \\
\hline Non-piscivorous & & 59 & 127 \\
\hline Total & & 324 & 350 \\
\hline \multicolumn{4}{|l|}{ Birds } \\
\hline Ajaia ajaja & Roseate spoonbill & 25 & \\
\hline Anhing a anhinga* & American anhinga & 13 & 2 \\
\hline Ardea herodias* & Great blue heron & 21 & 19 \\
\hline Butorides striatus* & Green heron & 23 & 2 \\
\hline Casmerodius albus* & Great egret & 78 & 7 \\
\hline Egretta thula* & Snowy egret & 233 & \\
\hline Eudocimus albus & White ibis & 143 & 14 \\
\hline Florida caerulea* & Little blue heron & 2 & \\
\hline Himantopus mexicanus & Black-necked stilt & 10 & \\
\hline Hydranassa tricolor* & Louisiana heron & 96 & 8 \\
\hline Megaceryle alcyon* & Belted kingfisher & 14 & \\
\hline Mycteria americana* & Wood stork & 28 & 8 \\
\hline Nycticorax nycticorax* & Blk.-crowned night heron & 4 & \\
\hline Pandion haliaetus* & Osprey & & 1 \\
\hline Pelecanus erythrorhynchos* & White pelican & & 4 \\
\hline Pelecanus occidentalis* & Brown pelican & 1 & 3 \\
\hline Phalacrocorax auritus* & Dbl.-crested cormorant & 3 & 7 \\
\hline \multirow[t]{3}{*}{ Plegadis falcinellus } & Glossy ibis & 112 & \\
\hline & Waterfowl & 87 & \\
\hline & Shorebirds & 32 & \\
\hline Piscivorous Birds & & 526 & 61 \\
\hline Non-Piscivorous Birds & & 409 & 14 \\
\hline Total & & 935 & 75 \\
\hline
\end{tabular}

Piscivores indicated by asterisk.

Ditches and small creeks may offer thermal refuge for fish during cold periods (Adams and Tremain 1999). During winter, water temperature in Banana Creek was lower than in the impoundment. The ditch is more protected from cold winds than the more exposed Banana Creek, and the surface area to depth ratio is greater in Banana Creek, allowing cold winds to have a greater influence on water temperature by mixing the water column. Despite potential refuge from low temperatures offered within the impoundment, large piscivorous fish occurred in low abundance 
during winter contrary to results from a large estuarine creek on Merritt Island connected to the Indian River Lagoon, where the highest abundances of $S$. ocellatus occurred during winter (Adams and Tremain 1999).

\section{Patterns of fish use}

Given that saltmarsh fish left the impoundment at over $200 \%$ greater biomass than entered, the marsh appears to function essentially as a net exporter of forage fish to the adjacent estuary. As water level receded, resident fish concentrated in ditches and creeks, and the youngest residents remained in deeper ponds on the marsh surface, consistent with data for tidal marshes (Kneib 1993; Rozas 1995). Crowding may have influenced the fish emigration to the estuary that ensued. In a Georgia tidal marsh, when Fundulus heteroclitus (Linnaeus) was added to experimental enclosures on the marsh surface at four times normal density for six weeks, one-third to three-fourths of the fish died or escaped (Kneib 1981). Fish at high densities also exhibited reduced growth rates and fecundity (Kneib 1981; Weisberg and Lotrich 1986). Kneib (1981) suggested that $F$. heteroclitus would not likely sustain densities at the high levels forced in his study, and would normally respond to high density by emigrating. In the present study, density-dependent effects may well have triggered the marked egress of resident fish from the impoundment. Monthly seining in the Merritt Island area shows an abundance of resident marsh fishes in the estuary (R. Paperno, Florida Fish and Wildlife Conservation Commission, personal communication). During spring, when water levels have receded from marshes, L. parva, Menidia spp., and C. variegatus rank among the top five most abundant species.

Resident fish movements from saltmarsh creeks to the estuary resulting from overcrowding may be unique to seasonally flooded marshes. In tidal systems, marsh residents move to creeks during low tide, but probably only occupy this habitat temporarily because access to the marsh surface will occur again only hours later. Thus, resident fish in such systems face crowded conditions in creeks for only a short period, contrary to seasonally flooded marshes that may remain dry for several months, prompting fish to move to the estuary in response to overcrowding. In tidal systems, movement of saltmarsh production to the estuary by residents may be limited to trophic interactions with larger transient fish that occur near creek entrances and along creek banks when residents are concentrated there at low tide (Kneib 1997).

An unexpected result during the study was the marked ingress of resident fish into the impoundment from the estuary at the onset of marsh flooding, which was also the time of observed schooling by P. latipinna along the estuary shoreline. These schooling fish may have been seeking food, spawning habitat, and refuge on the marsh surface as soon as it became available. The low density of fish in the impoundment ditch and creek, and their presence on the marsh surface at the onset of marsh flooding during the same period, provide evidence that fish migrated into the impoundment and directly onto the marsh surface.

The marsh was flooded for over 6 months (55\% of the time during the study period), allowing resident fish to occupy the marsh surface continuously, far longer than would be typical for tidally influenced regions. For comparison, saltmarshes in Georgia are flooded on average about $26 \%$ annually, and saltmarshes in Louisiana are flooded on average about $35 \%$ annually (estimated from Figure 1, Kneib 1997). Of the resident fishes on the marsh surface, the great increases in population biomass of $C$. variegatus (4.2 times greater biomass leaving than entering) and $F$. grandis (8.5 times greater biomass leaving than entering) may indicate that they are best able to exploit saltmarsh foods and avoid predation. In tidal marshes, growth rates of larval $F$. heteroclitus positively correlated with marsh flooding duration (Kneib 1993). Resident fish of the seasonally flooded marshes of the northern Indian River Lagoon may benefit from increased growth rates and reproductive output where they have the opportunity to exploit saltmarsh resources continuously; a hypothesis yet to be tested.

The hypothesis that juvenile transient fish enter the impoundment, grow, and eventually emigrate to the estuary in greater biomass (although fewer individuals) than when they entered was supported by the greater number of $M$. cephalus in the impoundment than along the estuary shoreline, and the movement of transient fish from the 
impoundment to the estuary. Other transient species expected to use the low salinity, quiescent waters associated with Banana Creek saltmarshes, such as E. saurus, and P. cromis, were not abundant in the study marsh as young juveniles. The distribution of juveniles, however, is spotty at best, and may be more influenced by spawning locations and transport patterns than by habitat quality alone (e.g., Miller et al. 1984; Ross and Epperly 1985). Thus, the specific site where this study was conducted may not have been in the right location to receive young juveniles other than $M$. cephalus. The low number of transients along the estuary shoreline rejects the possibility that young transient fish are abundant along the shoreline, but absent from the impoundment.

\section{Piscivores}

The lack of recaptured large piscivorous fish within the impoundment, combined with high abundance each month, suggest that the exchange of large predators between the impoundment and estuary was high. Large fish entered the impoundment for short periods (at least less than a month). Capture of large fish moving through culverts also supports the hypothesis that the exchange rate of piscivorous fish was high. Although $53 \%$ of gill-net captured fish that died had empty stomachs (possibly a result of regurgitation due to stress upon gill net capture), piscivorous fish stomachs did contain resident fishes. Nevertheless, the hypothesis that large piscivorous fish enter the impoundment, use the impoundment briefly as a feeding station, and then leave was supported by the results. There was no evidence that predators were more abundant along the shoreline than in the impoundment, or that predators were trapped within the impoundment or killed as a result of suboptimal water conditions.

The low piscivorous fish catch per unit effort during winter may result from reduced activity of large fish during periods of low water temperatures, or avoidance of the study area during winter. The absence of large piscivorous fish during low winter water levels allows resident fish to leave the impoundment with minimum predation by large fish.

Average annual piscivorous bird abundance in the study marsh $\left(0.51\right.$ birds ha $\left.{ }^{-1}\right)$ was less than the average reported for other Merritt Island impoundments $\left(0.62\right.$ birds ha $^{-1}$; Smith and Breininger 1995). The highest abundance of birds occurs in saltmarsh impoundments that are closed nearly year round (E. Stolen, Dynamac Corporation, personal communication), presumably where standing stock of resident fish is greater as a result of longer hydroperiod, lower predation by transient fish, and absence of fish emigration to the estuary. In the open impoundment of the present study, piscivorous bird abundance was influenced by major fish movements as evidenced by the August bird aggregation on the marsh surface following movement of fish into the marsh, and the bird aggregation along ditches and creeks as fish moved to these areas as water levels receded.

\section{Comparative fish use of marsh habitats}

The estuary shoreline, although vegetated with marsh plants, is not equivalent to the marsh surface with respect to fish community composition and abundance (Klassen 1998; present study). For example, the dominant species along the shoreline during the present study was $F$. carpio, an incidental marsh species, and not the typical suite of resident species found within the impoundment. Furthermore, resident fish densities were greater within the impoundment habitats than along the shoreline. Klassen (1998) found that some species used Indian River Lagoon impoundment creeks and ditches (e.g., Mugil cephalus), while others may occur only along the estuary shoreline (e.g., L. xanthurus, C. nebulosus, Lagodon rhomboides (Linnaeus), Strongylura marina (Walbaum), and Symphurus plagiusa (Linnaeus)).

Culverts connecting the impoundment to the estuary offer feeding opportunities to a variety of fish and wildlife. Alligators were observed within culverts on two occasions presumably ambushing large transient fish, birds were often observed perched above culverts or feeding near culvert entrances, and large piscivorous fish were observed feeding at culvert outfall plumes (P. Stevens, personal observations). Culverts confine water flow between the impoundment and estuary to a small area, thereby concentrating potential food sources for predators. A previous study found that culverts located near creek 
entrances or within embayments received the greatest use by fish (Wieher 1995), and subsequent reconnection of impoundments with culverts often occurs at these locations, as was the case in the study impoundment.

The perimeter ditch, although artificial, can be an important habitat for large piscivorous fish seeking prey (Gilmore et al. 1982; Rey et al. 1990b; present study). Water conditions in the study impoundment ditch (low dissolved oxygen and redox potential) were not substantially different than in adjacent Banana Creek, and large transient piscivores were present in the ditch year round. Compared to many other Indian River Lagoon impoundments, the study impoundment is well connected (eight culverts connecting it to Banana Creek). Many impoundments have only one culvert and this may not be open or maintained. Water conditions in the perimeter ditches associated with these, and other less actively managed impoundments, may be an important concern. The deep-water ditch may initially attract transient fish, but sudden degradation of water conditions due to inadequate circulation could kill these fish resulting in a net 'sink' for transient fish (Poizat and Crivelli 1997).

Impounded shallow creeks are a conspicuous feature in the northern Indian River Lagoon, often separating adjacent impoundments, but little attention has been given to their value and potential restoration. The seasonal difference in resident fish use between the impoundment creek and the ditch may be related to changes in water level. The impoundment creek is much shallower than the perimeter ditch, which may explain its preference by resident fish when water level is low and the marsh surface is not available. The greater surface area of the creek may provide more food (e.g., microalgae), and cover (too shallow for large piscivorous fish), allowing resident fish to maximize growth and minimize predation in the absence of marsh surface access. Thus, shallow creeks may provide an alternative habitat to the marsh surface for resident fish during spring through summer. These creeks also appear to be important feeding areas for large piscivorous fish and birds when water levels allow access to the marsh fish.

\section{Conclusions}

Mugil cephalus used the saltmarsh impoundment as a nursery, but other expected nursery species (e.g., E. saurus, P. cromis) were not abundant as young juveniles within the impoundment or along the estuary shoreline. Resident fish are important forage for large piscivorous fish, and these predators regularly entered the marsh to prey upon marsh fish in the study impoundment where eight culverts connect it to the estuary. Also, piscivorous birds congregated within the impoundment to feed upon resident fish. Despite predation by fish and birds within the impoundment, resident fish leave the impoundment in far greater biomass than enter, substantially contributing to the estuary prey base. Although the movement of marsh production across the landscape by trophic relay occurred as large transients ate small residents and then left, the resident fish themselves emigrated from the impoundment in substantial biomass, perhaps a unique occurrence of seasonally flooded saltmarshes.

\section{Acknowledgements}

This research was supported by the US Geological Survey Coastal Restoration Initiative. The refuge managers and staff at Merritt Island National Wildlife Refuge provided access to field sites and knowledge of impoundment ecology. A. Quaid maintained water quality data loggers. C. Bennett, J. Berg, N. Flavin, M. Randall, E. Rolla, J. Russell, P. Schofield, M. Schreiner, S. Stahl, G. Stevens, and G. Yeargin provided assistance in the field and laboratory. T. Crisman, F. Percival, and G. Dennis provided constructive and helpful comments in the development of the manuscript. 


\section{Appendix A}

Appendix A. Length-weight relationships for dominant nekton collected within Merritt Island National Wildlife Refuge, Florida.

\begin{tabular}{|c|c|c|c|c|c|c|}
\hline $\log _{\mathrm{e}}(\mathrm{Wt})=\log _{\mathrm{e}}(\mathrm{TL})^{*}$ & a & + & $\mathrm{b}$ & No. & $\mathrm{r}$ & Size range $(\mathrm{mm} \mathrm{TL})$ \\
\hline Alpheus heterochaelis & 3.062 & & -10.825 & 18 & 0.967 & $25-55$ \\
\hline Anchoa mitchilli & 2.919 & & -11.256 & 39 & 0.950 & $17-66$ \\
\hline Arius felis $^{\mathrm{a}}$ & 3.081 & & -12.235 & 52 & 0.851 & $301-390$ \\
\hline Cynoscion nebulosus & 2.885 & & -10.970 & 21 & 0.994 & $29-422$ \\
\hline Cynoscion nebulosus ${ }^{\mathrm{a}}$ & 3.084 & & -12.113 & 41 & 0.958 & $250-460$ \\
\hline Cyprinodon variegatus & 3.610 & & -12.855 & 349 & 0.991 & $17-52$ \\
\hline Elops saurus & 2.964 & & -11.973 & 42 & 0.984 & $159-462$ \\
\hline Floridichthys carpio & 3.385 & & -12.353 & 29 & 0.994 & $47-69$ \\
\hline Fundulus confluentus & 3.477 & & -13.063 & 28 & 0.996 & $30-71$ \\
\hline Fundulus grandis & 3.201 & & -12.077 & 63 & 0.989 & $43-106$ \\
\hline Gambusia holbrooki & 3.189 & & -12.113 & 198 & 0.984 & $10-40$ \\
\hline Gobiosoma bosc & 2.890 & & -10.527 & 150 & 0.903 & $11-39$ \\
\hline Gobiosoma robustum & 3.012 & & -10.833 & 486 & 0.910 & $8-34$ \\
\hline Jordanella floridae & 3.234 & & -11.505 & 56 & 0.971 & $19-41$ \\
\hline Leiostomus xanthurus & 3.069 & & -11.524 & 108 & 0.997 & $39-173$ \\
\hline Leiostomus xanthurus $^{\mathrm{a}}$ & 3.448 & & -13.597 & 31 & 0.964 & $171-321$ \\
\hline Lepisosteus platyrhincus ${ }^{\mathrm{a}}$ & 2.692 & & -10.293 & 110 & 0.819 & $370-615$ \\
\hline Lucania parva & 3.059 & & -10.884 & 743 & 0.900 & $8-40$ \\
\hline Menidia spp. & 3.035 & & -12.032 & 107 & 0.972 & $32-98$ \\
\hline Microgobius gulosus & 3.099 & & -12.121 & 174 & 0.974 & $17-71$ \\
\hline Mugil cephalus & 3.114 & & -11.507 & 91 & 0.915 & $32-52$ \\
\hline Mugil cephalus $^{\mathrm{a}}$ & 3.252 & & -13.042 & 306 & 0.982 & $105-475$ \\
\hline Palaemonetes pugio & 3.052 & & -11.697 & 402 & 0.850 & $17-38$ \\
\hline Poecilia latipinna & 3.141 & & -11.519 & 450 & 0.990 & $15-59$ \\
\hline Sciaenops ocellatus & 2.976 & & -11.382 & 30 & 0.933 & $286-380$ \\
\hline Strongylura notata & 3.277 & & -14.724 & 37 & 0.982 & $71-320$ \\
\hline Syngnathus scovelli & 3.455 & & -16.225 & 162 & 0.965 & $25-83$ \\
\hline Trinectes maculatus & 3.247 & & -11.897 & 18 & 0.955 & $52-81$ \\
\hline
\end{tabular}

${ }^{\text {a }}$ Measured in the field and weighed with a spring scale. All other lengths and weights taken in the laboratory.

\section{References}

Adams D.H. and Tremain D.M. 1999. Association of large juvenile red drum, Sciaenops ocellatus, with an estuarine creek on the Atlantic coast of Florida. Environ. Biol. Fishes 58: 183-194.

Brockmeyer R.E., Rey J.R., Virnstein R.W., Gilmore R.G. and Earnest L. 1997. Rehabilitation of impounded estuarine wetlands by hydrologic reconnection to the Indian River Lagoon, Florida (USA). Wetlands Ecol. Manage. 4: 93-109.

Duncan W.H. and Duncan M.B. 1987. The Smithsonian Guide to Seaside Plants of the Gulf and Atlantic Coasts from Louisiana to Massachusetts, Exclusive of Lower Peninsular Florida. Smithsonian Institution Press, Washington, DC, and London.

Faunce C.H. and Paperno R. 1999. Tilapia-dominated fish assemblages within an impounded mangrove ecosystem in east-central Florida. Wetlands 19: 126-138.

Gilmore R.G., Cooke D.W. and Donohoe C.J. 1982. A comparison of the fish populations and habitat in open and closed salt marsh impoundments in east-central Florida. Northeast Gulf Sci. 5: 25-37.
Harrington R.W. Jr. and Harrington E.S. 1961. Food selection among fishes invading a high subtropical salt marsh from the onset of flooding through the progress of a mosquito brood. Ecology 42: 642-666.

Harrington R.W. Jr. and Harrington E.S. 1982. Effects on fishes and their forage organisms of impounding a Florida salt marsh to prevent breeding by salt marsh mosquitoes. Bull. Marine Sci. 32: 523-531.

Kangas P.C. and Lugo A.E. 1990. The distribution of mangroves and saltmarsh in Florida. Trop. Ecol. 31: 32-39.

Karlen D.J. 1991. A comparison of the water quality, benthic infauna and macrofauna between an impounded and a natural tidal creek. M.S. Thesis. Florida Institute of Technology, Melbourne, Florida.

Klassen C.A. 1998. The utilization of a Florida salt marsh mosquito impoundment by transient fish species. M.S. Thesis, Florida Institute of Technology, Melbourne, FL.

Kneib R.T. 1981. Size-specific effects of density on the growth, fecundity, and mortality of the fish Fundulus heteroclitus in an intertidal salt marsh. Marine Ecol. Progr. Ser. 6: 203-212.

Kneib R.T. 1993. Growth and mortality in successive cohorts of fish larvae within an estuarine nursery. Marine Ecol. Progr. Ser. 94: 115-127. 
Kneib R.T. 1997. The role of tidal marshes in the ecology of estuarine nekton. Oceanogr. Marine Biol.: Annu. Rev. 1997 35: $163-220$.

Lin J. and Beal J.L. 1995. Effects of mangrove marsh management on fish and decapod communities. Bull. Marine Sci. 57: 193-201.

Meador M.R. and Kelso W.E. 1990. Growth of largemouth bass in low salinity environments. Trans. Am. Fish. Soc. 119: $545-552$.

McLaughlin B.J.P. 1982. A study of the fish population and habitat of an ecologically designed mosquito impoundment. M.S. Thesis. Florida Institute of Technology, Melbourne, FL.

Miller J.M., Ross S.W. and Epperly S.P. 1984. Habitat choices in estuarine fish: do they have any? In: Copeland B.J. (ed.), Research for Managing the Nation's Estuaries. Proceedings of a conference in Raliegh North Carolina, North Carolina, pp. 337-352.

Montague C.L., Zale A.V. and Percival H.F. 1987. Ecological effects of coastal marsh impoundments: a review. Environ. Manage. 11: 743-756.

Poizat G. and Crivelli A.J. 1997. Use of seasonally flooded marshes by fish in a Mediterranean wetland: timing and demographic consequences. J. Fish Biol. 51: 106-119.

Poulakis G.R., Shenker J.M. and Taylor D.S. 2002. Habitat use by fishes after tidal reconnection of an impounded estuarine wetland in the Indian River Lagoon FL (USA). Wetlands Ecol. Manage. 10: 51-69.

Provost M.W. 1973. Mean high water mark and use of tidelands in Florida. Florida Sci. 1: 50-66.

Rey J.R., Shaffer J., Tremain D., Crossman R.A. and Kain T. 1990a. Effects of re-establishing tidal connections in two impounded subtropical marshes on fishes and physical conditions. Wetlands 10: 27-45.

Rey J.R., Peterson M.S., Kain T.R., Vose F.E. and Crossman R.A. 1990b. Fish populations and physical conditions in ditched and impounded marshes in east-central, Florida. Northeast Gulf Sci. 11: 163-170.

Robins C.R., Bailey R.M., Bond C.E., Brooker J.R., Lachner E.A., Lea R.N. and Scott W.B. 1991. Common and Scientific Names of Fishes from the United States and Canada, 5th edn. American Fisheries Society, Special Publication 20, Bethesda, MD, USA.

Rogers D.R., Rogers B.D. and Herke W.H. 1994. Structural marsh management effects on coastal fishes and crustaceans. Environ. Manage. 18: 351-369.
Ross S.W. and Epperly S.P. 1985. Utilization of shallow estuarine nursery areas by fishes in Pamilco Sound and adjacent tributaries, North Carolina. In: Yanez-Arancibia A. (ed.), Fish Community Ecology in Estuaries and Coastal Lagoons: Towards an Ecosystem Integration. DR R UNAM Press, Mexico, pp. 207-232.

Rozas L.P. 1995. Hydroperiod and its influence on nekton use of the salt marsh: a pulsing ecosystem. Estuaries 18: 579-590.

Schoor M.S., Meador M.R. and Hill L.G. 1995. Incidental catch of sport fish in cast nets used to collect baitfish in Lake Texoma, Oklahoma, Texas. North Am. J. Fish. Manage. 15: $142-147$.

Smith N.P. 1986. The rise and fall of the estuarine intertidal zone. Estuaries 9: 95-101.

Smith R.B. and Breininger D.R. 1995. Wading bird populations of the Kennedy Space Center. Bull. Marine Sci. 57: 230-236.

Snelson F.F. 1983. Ichthyofauna of the northern part of the Indian River Lagoon System, Florida. Florida Sci. 46: 187 206.

Sokal R.R. and Rohlf F.J. 1995. Biometry. W. H. Freeman and Company, New York.

Stevens P.W. 1999. The vacillation between saltmarsh and mangrove communities at the transition between temperate and subtropical climate in Florida. M.S. Thesis. University of Florida, Gainesville, FL.

Taylor D.S., Poulakis G.R., Kupschus S.R. and Faunce C.H. 1998. Estuarine reconnection of an impounded mangrove salt marsh in the Indian River Lagoon, Florida: short-term changes in fauna. Mangroves Saltmarshes 2: 29-36.

Taylor W.W. and Gerking S.D. 1978. Potential of the Ohrid rifle minnow, Alburnoides bipunctatus ohridanus, as an indicator of pollution. Ver. Int. Ver. Theoret. Angew. Limnol. 20: 2178-2181.

Terres J.K. 1980. The Audobon Society Encyclopedia of North American Birds. Alfred A. Knopf, New York.

Wieher C.R. 1995. The movement of juvenile fishes between the Indian River Lagoon and mosquito impoundments north of Sebastian Inlet, Florida. M.S. Thesis. Florida Institute of Technology, Melbourne, FL.

Weisberg S.B. and Lotrich V.A. 1986. Food limitation of a Delaware salt marsh population of the mummichog, Fundulus heteroclitus (L.). Oecologia 68: 168-173. 